\title{
Common Deletion (CD) in mitochondrial DNA of irradiated rat heart
}

\author{
RAQUEL G. SIQUEIRA ${ }^{1,2}$, DAYSE A. DA SILVA ${ }^{2}$, LUIZ D.B. DE MELO ${ }^{3}$, ELIZEU F. DE CARVALHO ${ }^{2}$, \\ SAMARA C. FERREIRA-MACHADO ${ }^{1}$ and CARLOS E.V. DE ALMEIDA ${ }^{1}$ \\ ${ }^{1}$ Laboratório de Ciências Radiológicas, Departamento de Biofísica, Instituto de Biologia Roberto Alcântara Gomes, \\ Universidade do Estado do Rio de Janeiro, Rua São Francisco Xavier, 524, Pavilhão Haroldo Lisboa da Cunha, \\ Térreo, Maracanã, 20550-900 Rio de Janeiro, RJ, Brasil \\ ${ }^{2}$ Laboratório de Diagnósticos por DNA, Departamento de Biologia Geral, Instituto de Biologia Roberto Alcântara Gomes, \\ Universidade do Estado do Rio de Janeiro, Rua São Francisco Xavier, 524, Pavilhão Haroldo Lisboa da Cunha, \\ Térreo, Maracanã, 20550-010 Rio de Janeiro, RJ, Brasil \\ ${ }^{3}$ Laboratório de Parasitologia Molecular, Departamento de Biofísica, Instituto de Biofísica Carlos Chagas Filho, \\ Universidade Federal do Estado do Rio de Janeiro, Cidade Universitária, 21949-900 Rio de Janeiro, RJ, Brasil
}

Manuscript received on August 17, 2012; accepted for publication on April 25, 2013

\begin{abstract}
The purpose of this study was to map the common deletion (CD) area in mtDNA and investigate the levels of this deletion in irradiated heart. The assays were developed in male Wistar rats that were irradiated with three different single doses $(5,10$ or $15 \mathrm{~Gy})$ delivered directly to the heart and the analyses were performed at various times post-irradiation ( 3,15 or 120 days). The CDs area were sequenced and the CD quantified by real-time PCR. Our study demonstrated that the $\mathrm{CD}$ levels progressively decreased from the $3^{\text {rd }}$ until the $15^{\text {th }}$ day after irradiation, and then increased thereafter. Additionally, it was observed that the levels of $\mathrm{CD}$ are modulated differently according to the different categories of doses (moderate and high). This study demonstrated an immediate response to ionizing radiation, measured by the presence of mutations in the $\mathrm{CD}$ area and a decrease in the CD levels.
\end{abstract}

Key words: cardiovascular complications, common mitochondrial DNA deletion, mediastinal tumours, radiotherapy.

\section{INTRODUCTION}

During radiotherapy (RT) of mediastinal tumours (lymphomas, breast cancer, and lung cancer), frequently a part of the heart is included in the treatment field and may receive significant doses of ionizing radiation (Hilbers et al. 2012). Clinical reports indicate that a considerable number of patients who receive this therapy develop cardiovascular complications. Radiation damage may affect the pericardium, myocardium

Correspondence to: Raquel Gomes Siqueira

E-mail: raquelgsiqueira@gmail.com or coronary vasculature characterised by fibrotic changes or small vessel damage (Rijswijk et al. 2008, Doyen et al. 2010).

Recent studies showed that the dose radiation typically used in RT, promotes a larger number of ionizations within the cytoplasm (and in the organelles residing therein), as compared to the nucleus (Nikjoo and Lindborg 2013). Therefore, looking more closely to an important organelle for energy metabolism of cardiac tissue, such as the mitochondria, it will provide important insight in how cardiac tissue might respond to RT. 
The mitochondria contain their own DNA (mtDNA) which encodes components of the respiratory chain, being of extreme importance for the synthesis of energy. Studies have shown that this molecule may be damaged by exogenous harmful agents such as ionizing radiation, since mtDNA lacks the protection of histones, contains no introns, is exposed continuously to endogenous reactive oxygen species (ROS) and has a less efficient repair system than nuclear DNA (Prithivirajsingh et al. 2004).

Although the mitochondrial genome encompasses a small fraction of the total genetic material in a cell, any damage or alteration to it can still have serious implications for a cell's viability and/ or survival (Murphy et al. 2005, Evdokimovsky et al. 2011) and can lead to the development of degenerative diseases with slowly progressing conditions often associated with impaired oxidative phosphorylation, especially in tissues with high energy expenditures such as the heart.

Various mutations have been induced in mtDNA after RT (Wardell et al. 2003). Among the various mutations, a large-scale deletion of $4977 \mathrm{bp}$ in humans and $4834 \mathrm{bp}$ in rodents (8103-8118 bp, 12937-12952 bp), the so-called common deletion (CD), has been reported after low-level ionizing radiation exposure (Ikushima et al. 2002, Murphy et al. 2005). However, the dynamic of CD levels after moderate and high-level ionizing radiation exposure, such as that of RT, has not been reported. Therefore, the purpose of this study was to map the $C D$ region in mtDNA and investigate the level of this deletion in mitochondrial DNA of cardiac tissue of a radiobiological model in Wistar rats employing doses similar to those used in RT.

\section{MATERIALS AND METHODS}

ANIMALS AND IRRADIATION

Male Wistar rats were obtained at three months of age and weighed approximately $250 \mathrm{~g}$. Rats were maintained on a $12 \mathrm{~h}$ light/dark cycle with food and water provided ad libitum. Animals were distributed into four groups ( $\mathrm{n}=15$ per group), and each group received a single dose irradiation $(0,5,10$ or $15 \mathrm{~Gy})$. The heart position was marked after Computed Tomography (HiSpeed CT/Dual, GE Healthcare, USA). Cardiac-specific irradiation was performed using a Varian Clinac $2100 \mathrm{C}$ linear accelerator (Variant Medical Systems, CA, USA) with a 6MV X-ray, and a dose rat of 240 centi-Gy/min. Individual rats were irradiated in supine position using an anterior field size of $3 \times 3 \mathrm{~cm}^{2}$ with bolus depth of $0.5 \mathrm{~cm}$. This study was approved by the local ethical council CEUA/010/2012 (Universidade do Estado do Rio de Janeiro).

Before irradiation, animals were anesthetised with $10 \%$ ketamina / $2 \%$ xilazina $(0.1 \mathrm{mg} / \mathrm{kg})$, intraperitoneally. Single doses of 10-15 Gy were calculated to be approximately equivalent to the total fractionated doses of 30-50 Gy (2 Gy per fraction), according to the Linear Quadratic model and an $\mathrm{a} / \mathrm{b}$ ratio of $2: 3$ as described by SchultzHector et al. (1992).

\section{DNA ISOLATION}

Euthanasia was performed 3, 15 or 120 days post-irradiation. The animals were anesthetised with $10 \%$ ketamina / $2 \%$ xilazina $(0.1 \mathrm{mg} / \mathrm{kg})$, intraperitoneally and approximately $100 \mathrm{mg}$ of the left ventricle were collected. Then, the samples of cardiac tissue were washed with ice-cold saline, minced and homogenised at $0-4{ }^{\circ} \mathrm{C}$ with a glass homogeniser by hand. After this procedure, total DNA was extracted by a standard extraction protocol using proteinase $\mathrm{K}$ and sodium dodecyl sulphate (SDS) according to methods previously described (Miller 1998). The concentration of DNA was measured by Biophotometer (Eppendorf) using $260 \mathrm{~nm}$ optical density.

PRESENCE OF THE COMMON DELETION BY SEQUENCING

The presence of mtDNA in each sample was proven by amplification of a $519 \mathrm{bp}$ fragment of a conserved 
control region present in $100 \%$ of all normal mtDNA (D-loop region) by conventional PCR. The primers to the D-loop and the $\mathrm{CD}$ from the rat mitochondrial genome (GenBank Accession No. X14848) were designed using the Primer 3 software (http:// frodo. wi.mit.edu/). In addition, we used BLAST to confirm that the primers chosen for both regions had exclusive homology with their target in rat mtDNA. The primers are shown in Table I.

TABLE I

Primers used for conventional PCR amplification of total mtDNA (D-loop) and deleted mtDNA (CD).

\begin{tabular}{|c|c|c|c|}
\hline Primer & Sequence 5 $\rightarrow 3$, & $\begin{array}{c}\text { Binding } \\
\text { site }\end{array}$ & Amplicon \\
\cline { 1 - 3 } D-loop F conv & GGT TCT TAC TTC & $15772-$ & \\
& AGG GCC ATC & 15792 & \multirow{2}{*}{519 bp } \\
\cline { 1 - 2 } D-loop R conv & GTG GAA TTT TCT & $16269-$ & \\
& GAG GGT AGG C & 16290 & \\
\cline { 1 - 2 } Del F conv & GTT CCC ATC AAT & $7978-$ & \multirow{2}{*}{307 bp } \\
& TCT ATT CCC AT & 8000 & \\
\cline { 1 - 2 } Del R conv & GAA GCC TGC & $13099-$ & \\
& TAG GAT GCT TC & 13118 & \\
\hline
\end{tabular}

The conventional PCR amplification of the D-loop region was carried out in a $25 \mu \mathrm{l}$ reaction volume consisting of $1 \mathrm{U}$ Platinum Taq DNA polymerase (Invitrogen), $5 \mathrm{M}$ each D-loop primer (Applied Biosystems), 4x reaction buffer, containing dNTPs (Invitrogen) and $25 \mathrm{ng}$ of total DNA. The thermocycling conditions included an initial denaturation phase at $94^{\circ} \mathrm{C}$ for $2 \mathrm{~min}$, then 35 cycles of denaturation at $94^{\circ} \mathrm{C}$ for $15 \mathrm{~s}$, annealing at $60^{\circ} \mathrm{C}$ for $30 \mathrm{~s}$, and extension at $72^{\circ} \mathrm{C}$ for $1 \mathrm{~min}$, followed by a final extension at $72^{\circ} \mathrm{C}$ for $5 \mathrm{~min}$.

The primers used for identification of the CD amplify sites adjacent to the deletion region. Conventional PCR of the CD was carried out in a $50 \mu 1$ mixture containing $200 \mathrm{ng}$ of total DNA, $10 \mu \mathrm{M}$ each D-loop primer (Applied Biosystems), $4 \mathrm{x}$ reaction buffer, containing dNTPs (Invitrogen), and $2 \mathrm{U}$ Platinum Taq DNA polymerase (Invitrogen). The thermal cycling conditions were as above. The PCR products were electrophoresed through a $2.0 \%$ agarose gel at $100 \mathrm{~V}$ for $40 \mathrm{~min}$ and visualised with ethidium bromide. Each product obtained with primers for the CD was gel-purified and directly sequenced using an ABI PRISM 310 (Applied Biosystems) with ABI PRISM 310 Genetic Analyzer software.

Absolute QuANTIFICATION OF THE COMMON DELETION BY THE STANDARD CURVE METHOD

The quantity of the $\mathrm{CD}$ in heart was measured by quantitative co-amplification of the mitochondrial D-loop and the mitochondrial deletion using a real-time PCR absolute DNA quantification method. To do so, it was necessary to construct a standard curve using serial dilutions of plasmids containing D-loop and CD fragments as previously described by Ye et al. (2008) with modifications. The products created from a conventional PCR positive control sample were excised from the agarose gel and purified using the DNALL-IN-ONE DNA Purification Kit (Biotools, Brazil) according to the manufacturer's instructions. The purified PCR products were cloned into the $\mathrm{pGEM}^{\circledR}-\mathrm{T}$ 3000 bp plasmid (Promega) in accordance with the manufacturer's instructions. Blue-white screening was performed before plasmids were isolated. The cloned products were amplified by conventional PCR using D-loop and CD primers for sequencing. The confirmed clones were renamed $\mathrm{pD}$-loop for the total mtDNA and pCD for the common deletion. The recombinant plasmid DNA was isolated and purified using QIAprep Spin and QIAGEN type 100 (Qiagen). The concentration of the DNA was measured by Biophotometer (Eppendorf) using $260 \mathrm{~nm}$ optical density, and the copy number was calculated according to the known molecular weight of the plasmid. Serial dilutions of each standard were made in the range of $10-10^{7}$ copies per $1 \mu \mathrm{l}$ according to Applied Biosystems instructions (Creating standards curves with genomic DNA or plasmids DNA templates for use in quantitative PCR. Tutorial Review, http://www6.appliedbiosystems. com/support/tutorials/pdf/quant_pcr.pdf). 
Primers and probes for the D-loop region and the $\mathrm{CD}$ region were previously described by Branda et al. (2002) (Table II). The proportion of the CD was quantified with a deletion 6'-FAM-labelled fluorogenic probe (position 12952-12983) and the total mtDNA was detected with a VIC-labelled fluorogenic probe (position 15795-15822). The PCR products from total mtDNA and the CD were 83 bp and 81 bp amplicons, respectively. Standard PCR amplification was carried out in a $15 \mu \mathrm{l}$ reaction volume consisting of $1 \mu \mathrm{l}$ of template DNA (10-10 7 copies of plasmid or $50 \mathrm{ng}$ of total DNA), TaqMan Universal Master mix $(7 \mu \mathrm{l})$,
$5 \mu \mathrm{M}$ each $\mathrm{CD}$ primer, $5 \mu \mathrm{M}$ each D-loop primer, and $10 \mu \mathrm{M}$ each $\mathrm{CD}$ and D-loop probe. All samples were tested in triplicate and all experiments were done under multiplex conditions, that is, primers and probes for both total mtDNA and CD were present in each reaction. The thermocycling conditions included an initial denaturation phase and hot start at $95^{\circ} \mathrm{C}$ for $10 \mathrm{~min}$; then 45 cycles of denaturation at $95^{\circ} \mathrm{C}$ for 15 $\mathrm{s}$ and annealing and extension at $60^{\circ} \mathrm{C}$ for $30 \mathrm{~s}$. The fluorescence spectra were monitored by Sequence Detection System Real Time ABI PRISM 7500 with 7500 System SDS Software v1.4 (Applied Biosystems).

TABLE II

A. Primers used in real time PCR for amplification of a fragment of the D-loop mtDNA and a fragment indicative of the presence of the $4834 \mathrm{mtDNA}$ deletion

(Branda et al. 2002). B. Probes used in real time PCR for hybridization D-loop region and the region of occurrence of the $4834 \mathrm{mtDNA}$ deletion (Branda et al. 2002).

\begin{tabular}{|c|c|c|c|}
\hline \multicolumn{4}{|c|}{$\mathbf{A}$} \\
\hline Primer & Sequence $5^{\prime} \rightarrow 3^{\prime}$ & Binding site & Amplicon \\
\hline D-loop F & GGT TCT TAC TTC AGG GCC ATC A & $15772-15793$ & \multirow{2}{*}{$83 \mathrm{pb}$} \\
\hline D-loop R & GAT TAG ACC CGT TAC CAT CGA GAT & $15854-15831$ & \\
\hline Del F & AAG GAC GAA CCT GAG CCC TAA TA & $8094-8116$ & \multirow{2}{*}{$81 \mathrm{pb}$} \\
\hline Del R & CGA AGT AGA TGA TCC GTA TGC TGT & $13008-12985$ & \\
\hline
\end{tabular}

\begin{tabular}{|c|c|c|}
\hline \multicolumn{3}{|c|}{ B } \\
\hline Probes & Sequence $5^{\prime} \rightarrow 3^{\prime}$ & Binding site \\
\hline D-loop & VIC - TTG GTT CAT CGT CCA TAC GTT CCC CTT A - MGB & $12952-12983$ \\
\hline Del & FAM - TCA CTT TAA TCG CCA CAT CCA TAA CTG CTG T - MGB & $15795-15822$ \\
\hline
\end{tabular}

\section{STATISTICAL ANALYSIS}

The CD percentage was calculated as: the copy number of the $\mathrm{CD}$ molecules divided by total mtDNA molecules $x$ 100. The significance of the differences between the values was tested with analysis of variance (ANOVA) and the TukeyKramer multiple comparison test using statistical software GraphPad Prism 5.0 (California, USA).

\section{RESULTS}

THE COMMON DELETION IN THE HEART OF IRRADIATED

ANIMALS

Pronounced PCR amplification of the CD was observed in all heart samples including the control ones. Sequencing of these amplification products confirmed the CD in all samples, and additional mutations were also present. The additional mutations were single-base substitutions and single-base deletions in the $16 \mathrm{bp}$ sequence that flank the $\mathrm{CD}$ as well as in nearer regions. These additional mutations were present only in irradiated samples, but there was no correlation to dose or to time after irradiation (Table III).

The real-time PCR quantitative analysis revealed that the percentage of CDs in total rat heart mtDNA varied from $1.06 \times 10^{-4} \%$ to $7.99 \times 10^{-4} \%$ in control and irradiated samples.

The common deletion accumulated with the passage of time, this event could be detected in all the control groups, where there was a progressive 
TABLE III

Single-base substitutions and single-base deletions were observed in the 16 bp sequence that characterize the $C D(R)$ and in adjacent regions $(P)$. Five samples were analyzed in each group.

\begin{tabular}{|c|c|c|c|}
\hline Time after irradiation & Dose & $\begin{array}{l}\text { Single-base substitution } \\
\text { (samples number) }\end{array}$ & $\begin{array}{c}\text { Single-base deletion } \\
\text { (samples number) }\end{array}$ \\
\hline \multirow{4}{*}{3 days } & Control & 0 & 0 \\
\hline & 5 Gy & $1(2$ subst. $\mathrm{P})$ & 0 \\
\hline & $10 \mathrm{~Gy}$ & 1 (2 subst. $\mathrm{P})$ & 0 \\
\hline & 15 Gy & 0 & $\begin{array}{l}1 \text { ( } 2 \text { del. } P) \\
1 \text { ( } 3 \text { del. } R)\end{array}$ \\
\hline \multirow{4}{*}{15 days } & Control & 0 & 0 \\
\hline & 5 Gy & $2(2$ subst. $\mathrm{P})$ & $1(3$ del. $\mathrm{P})$ \\
\hline & $10 \mathrm{~Gy}$ & $\begin{array}{l}2 \text { (3 subst. P) } \\
1 \text { (1 subst. R) }\end{array}$ & 2 (1 del.P) \\
\hline & $15 \mathrm{~Gy}$ & 2 (3 subst. $\mathrm{P})$ & 2 (2 del. $\mathrm{R})$ \\
\hline \multirow{4}{*}{120 days } & Control & 0 & 0 \\
\hline & 5 Gy & 0 & 0 \\
\hline & $10 \mathrm{~Gy}$ & 0 & $1(1$ del. $\mathrm{P})$ \\
\hline & $15 \mathrm{~Gy}$ & $1(1$ subst. $\mathrm{P})$ & 0 \\
\hline
\end{tabular}

increase in the CD levels at 3,15 and 120 days. On the other hand, the amount of the CD in the irradiated groups decreased significantly over time, when compared to the controls (Figure 1).
The results at three days after the 5 Gy heart irradiation show a small decrease in the amount of deleted mtDNA. However, this difference was not significant in relation to the corresponding control

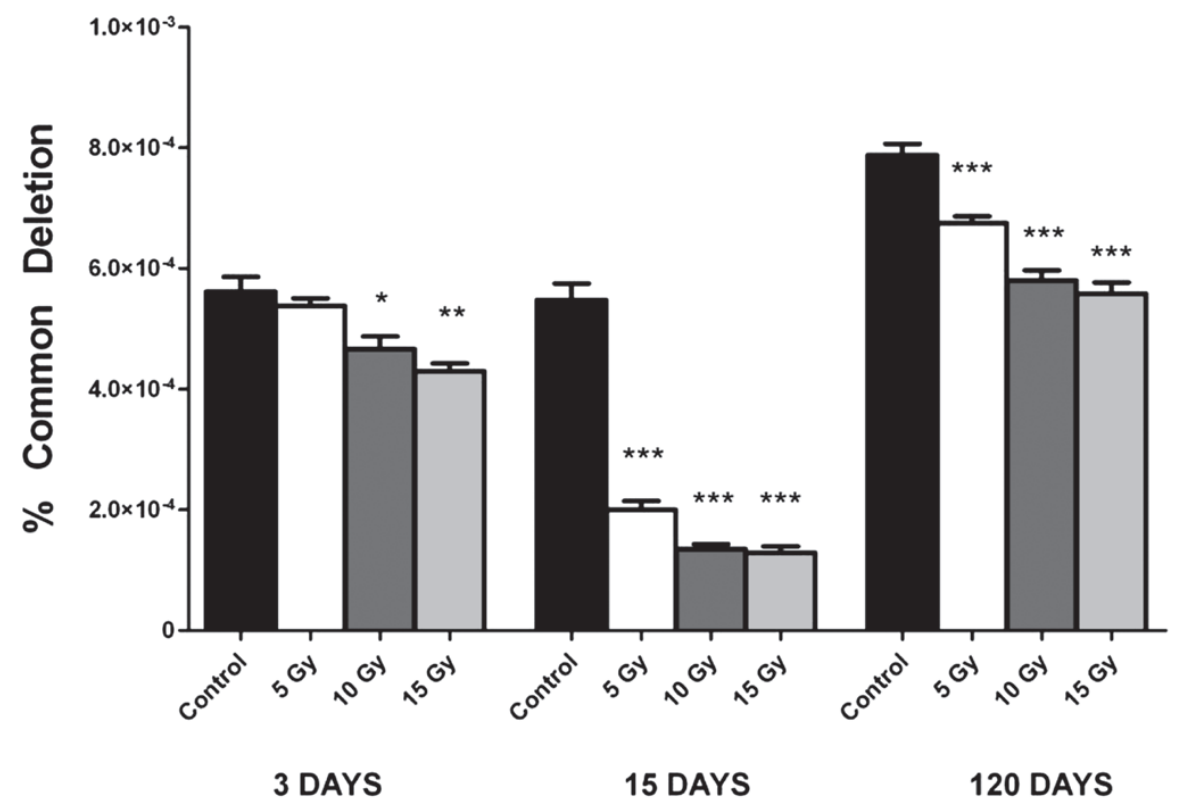

Figure 1 - Quantification by Real Time PCR of CD levels in cardiac tissue of rats irradiated with doses of 5, 10 or $15 \mathrm{~Gy}$ and their controls at different times after irradiation. The differences between the irradiated groups and its control were analyzed with analysis of variance (ANOVA) and the Tukey-Kramer post hoc test. Error bars represent standard deviation (SD). Statistical significance was accepted when $(P<0.05 *),{ }^{* *}(P<0.01)$ and $* * *(P<0.001)$. 
group $(P>0.05)$. In addition, the doses of $10 \mathrm{~Gy}$ and 15 Gy induced large reductions in the CD level $P<0.05$ for 10 Gy and $P<0.01$ for 15 Gy) at this point of time (Figure 1).

At 15 days after the irradiation a strong reduction in $\mathrm{CD}$ levels was observed in all the irradiated heart samples. All the doses yielded significant differences relative to the corresponding control ones $(P<0.001)$ (Figure 1).

The analysis at 120 days after the irradiation showed that after the initial sharp drop in CD levels, the cardiac tissue partially recovered

A

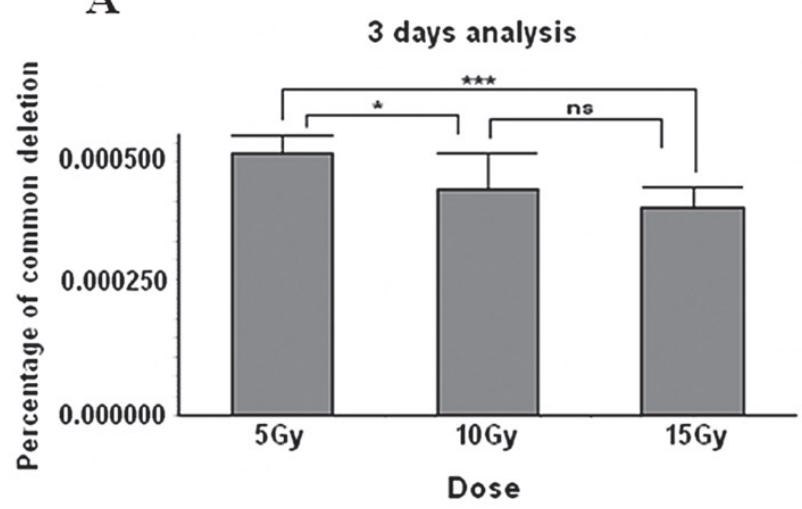

the number of deleted molecules. All the doses showed significant differences relative to the corresponding control ones $(P<0.001)$ (Figure 1).

This multiple comparison analysis between the irradiated groups showed that the dose of 5 Gy induced the lowest reduction of CD levels in heart compared to the highest doses at all time points. We also observed that the effects of the highest doses (10 and 15 Gy) were not significantly different from each other $(P>0.05)$, indicating that these doses have similar biological effects (Figure 2).
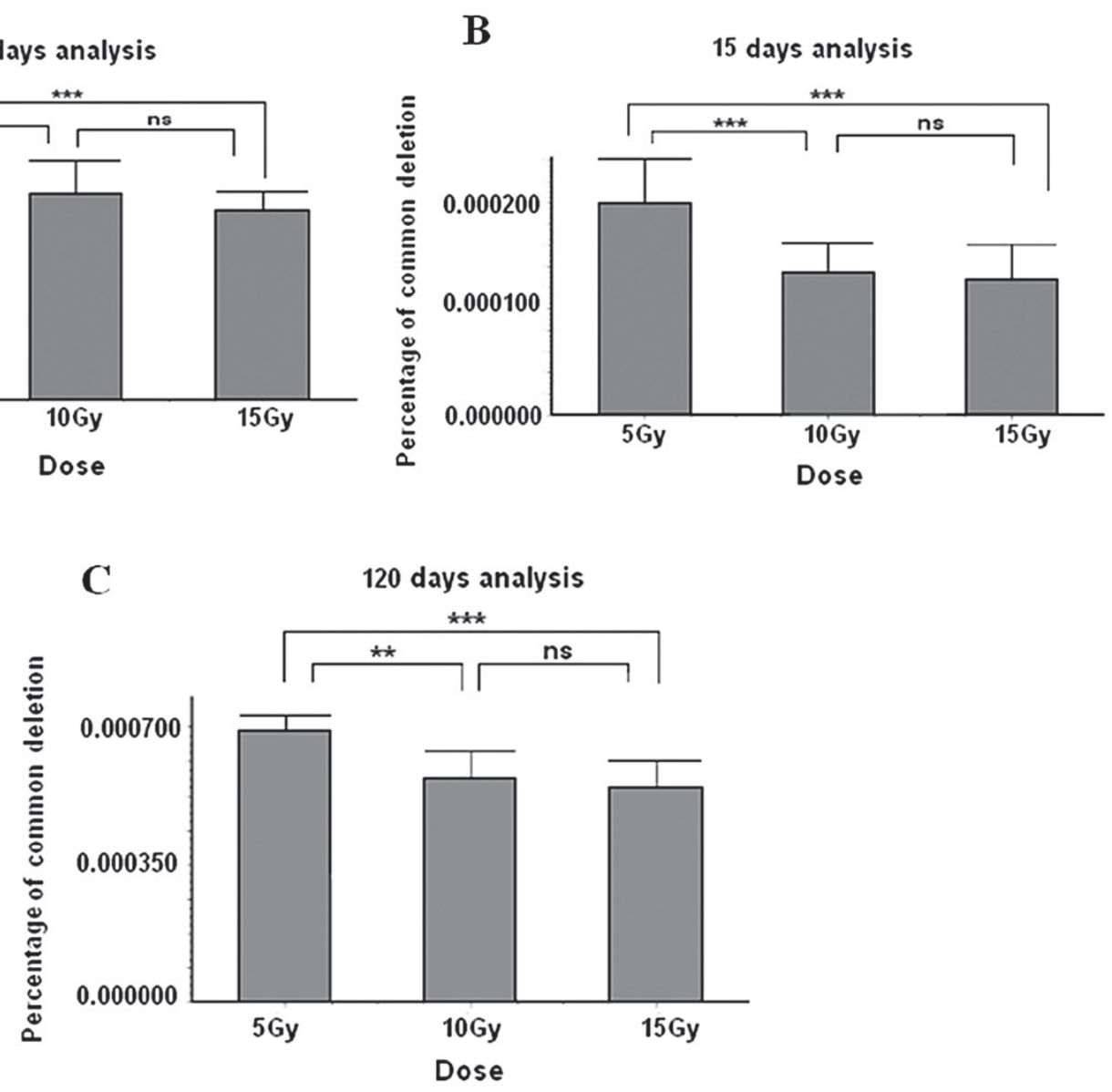

Figure 2 - Comparative analyses between the irradiated groups with doses of 5, 10 or 15 Gy at 3 days (A), 15 days (B) and 120 days (C) after irradiation. The differences between the irradiated groups were analyzed with analysis of variance (ANOVA) and the Tukey-Kramer post hoc test. Error bars represent standard deviation (SD). Statistical significance was accepted when $(P<0.05 *), * *(P<0.01)$ and $* * *(P<0.001)$; ns (difference not significant). 


\section{DISCUSSION}

In our study initially the CD was identified in cardiac tissue of both irradiated and control groups. The quantitative analysis showed an increase in CD frequency in the control groups by the time passing, which is in agreement with previous studies that related the accumulation of this deletion in tissues with low rates of cellular division, such as the cardiac tissue to the natural process of ageing (Zhong et al. 2011). On the other hand, only the irradiated cardiac tissue presented mutations in the 16 bp sequences that flank the $\mathrm{CD}$ as well as mutations in nearer regions, indicating radiationinduced damage in mtDNA.

In the irradiated cardiac tissue a reduction of CD levels (relative to control rats) was observed with all doses used and at all points of time after irradiation, indicating the existence of radiationinduced modifications in the cardiac tissue, reflected in the physiological alteration of the CD levels.

Few studies have been conducted involving ionizing radiation and the $\mathrm{CD}$, however they have used cell cultures and low to moderate doses (0.05-5 Gy) (Murphy et al. 2005, Pogozelski et al. 2006, Wang et al. 2007). In these studies the CD accumulations were observed only in irradiated cells with low doses; to moderate dose of 5Gy accumulation of $\mathrm{CD}$ was also observed, but their levels declined 24 hours after irradiation, in this case, Wang et al. (2007) associated the decreases in the levels of this deletion to cell death.

It is known that the accumulation of CDs is associated with oxidative stress generated by ionizing radiation (Murphy et al. 2005, Ikushima et al. 2002). However, these CD generated by oxidative stress were only seen in cells treated with low doses of ionizing radiation, on the contrary a reduced in CD levels are observed in cells treated with high doses of ionizing radiation (Wang et al. 2007). In our study, likewise, moderate and high doses induced reductions in these CD levels.
Additionally, the results of sequencing, which revealed the presence of additional mutations in the irradiated samples, may help in understanding the reductions in the levels of deletion observed until the $15^{\text {th }}$ day after irradiation. This reduction may have occurred by action of a mechanism of selection, where there were preferential gradual degradation of mtDNA with excessive accumulation of mutations (common deletion pre-existing + radiation induced mutations). Shokolenko et al. 2009 suggest a mechanism for the protection of mtDNA against oxidative insults, whereby a higher incidence of lesions to this molecule induces degradation of damaged mtDNA and prevents the accumulation of mutagenic base lesions. Furthermore, Kim et al. 2007 related another mechanism of degradation of no functional mitochondria (carrying molecules containing excess mutations), this mechanism has been described to elimination of aged and dysfunctional mitochondria; it is also called mitophagy, where autophagic and delivery to lysosomes for hydrolytic degradation occurs.

More significant reductions in cardiac tissue CD levels occurred when doses of 10 and 15 Gy were used. Their effects were similar at all points of time. It is probable that these doses induced intense damage in the mtDNA. This observation demonstrates that levels of $\mathrm{CD}$ are modulated differently according to the different categories of doses (low, moderate and high).

In this work, at all doses there was a partial recovery of the $C D$ levels observed in the $120^{\text {th }}$ day. The later recovery of $\mathrm{CD}$ levels has not been reported in previous studies. However, it is known that animal models of cardiac injuries display subsequent increases in the number of mitochondria, which occurs to compensate for energy levels necessary to maintain cardiac function (Russell et al. 2005). This increase in the number of mitochondria is associated with the replication of the genetic material. Moreover, the biogenesis of mtDNA is related to increased CD levels, as 
the deleted mtDNA is more easily replicated than wild-type mtDNA (Elson et al. 2001). It is possible that the increase in $\mathrm{CD}$ levels observed at 120 days after irradiation of cardiac tissue occurred due to increases in the number of mitochondria in conjunction with the replicative advantage of deleted mtDNA.

Although it can be considered a compensatory mechanism, a previous study developed by our group showed that the increase in the number of mitochondria (and mtDNA) does not necessarily imply in the recovery of the damaged cardiac tissue, since a deficit in myocardial contraction was observed in Wistar rats 120 days after irradiation with a dose of 15 Gy (FerreiraMachado et al. 2010).

It is important to mention that this was a preliminary study about the effects of RT on the mtDNA in cardiac tissue, where radiationinduced damage in this molecule were observed. Considering the important role that the mitochondria have in cell energy metabolism, especially when it comes to muscle cell, further studies are needed to investigate the extent of injuries to this organelle, to its genetic material and its consequences cardiac tissue. Furthermore, the hypotheses proposed in our study must be supported by these future studies.

\section{ACKNOWLEDGMENTS}

We acknowledge Dr. Rodolpho Albano (Instituto de Biologia Roberto Alcântara Gomes, Universidade do Estado do Rio de Janeiro, Brasil) who helped with cloning experiments. This project has been supported by Coordenção de Aperfeiçoamento de Pessoal de Nível Superior (CAPES/Brazil).

\section{RESUMO}

O propósito deste estudo foi mapear a região de "deleção comum" no mtDNA e investigar os níveis desta deleção no coração irradiado. Os ensaios foram desenvolvidos em ratos Wistar machos que foram irradiados com três diferentes doses únicas $(5,10$ ou 15 Gy), direcionadas ao coração, e as análises foram realizadas em diferentes tempos após irradiação (3,15 ou 120 dias). A região de "deleção comum" foi sequenciada e esta deleção foi quantificada através de PCR em tempo real. Nosso estudo mostrou que os níveis da "deleção comum" foram reduzidos progressivamente do $3^{\circ}$ até o $15^{\circ}$ dia após irradiação, e então aumentaram após este período. Adicionalmente, foi observado que os níveis da "deleção comum" são diferentemente modulados de acordo com as diferentes categorias de doses (moderada ou alta). Este estudo mostrou que há uma resposta imediata a radiação ionizante, mensurada através da presença de mutações na área de "deleção comum" e do decréscimo nos níveis desta deleção.

Palavras-chave: complicações cardiovasculares, deleção comum no DNA mitochondrial, tumores na região do mediastino, radioterapia.

\section{REFERENCES}

BRANDA RF, BROOKS EM, CHEN Z, NAUD SJ AND NICKLAS JA. 2002. Dietary modulation of mitochondrial DNA deletions and copy number after chemotherapy in rats. Mutat Res 501(1-2): 29-36.

Doyen J, GiRAud P AND BelKaCEMI Y. 2010. Normal tissue tolerance to external beam radiation therapy: cardiac structures. Cancer Radiother 14(4-5): 319-326.

Elson JL, SAMUEls DC, TURnBUll DM AND CHINNERY PF. 2001. Random intracellular drift explains the clonal expansion of mitochondrial DNA mutations with age. Am J Hum Gen 68(3): 802-806.

EVDOKIMOVSKY EV, USHAKOVA TE, KUDRIAVTCEV AA AND GAZIEV AI. 2011. Alteration of mtDNA copy number, mitochondrial gene expression and extracellular DNA content in mice after irradiation at lethal dose. Radiat Environ Biophys 50(1): 181-188.

FERREIRA-MACHADO SC ET AL. 2010. Up-regulation of angiotensin-converting enzyme and angiotensin II type 1 receptor in irradiated rats. Int J Radiat Biol 86(10): 880-887.

Hilbers FS, Boekel NB, Van Den Broek AJ, Van Hien R, Cornelissen S, Aleman BM, VAN 'T Veer LJ, VAN LEEUWEN FE AND SCHMIDT MK. 2012. Genetic variants in TGF $\beta-1$ and PAI-1 as possible risk factors for cardiovascular disease after radiotherapy for breast cancer. Radiother Oncol 102(1): 115-21.

IKUSHIMA T, ANDOH T, KAIKAWA T AND HASHIGUCHI K. 2002. Induction of a large deletion in mitochondrial genome of mouse cells induced by X-ray irradiation. Int Congr 1236: 331-334.

KiM I, RodRIGUEZ-ENRIQUEZ S AND LEMASTERS JJ. 2007. Minireview: selective degradation of mitochondria by mitophagy. Arch Biochem Biophys 462(2): 245-253. 
MiLler SA. 1998. Simples Salting out Procedure for extraction DNA from human nucleated cells. Nucleic Acids Res 16: 1215.

Murphy JEJ, Nugent S, Seymoura C And Mothersill C. 2005. Mitochondrial DNA point mutations and a novel deletion induced by direct low-LET radiation and by medium from irradiated cells. Mutat Res 585(1-2): 127-136.

NiKJOO HAND LINDBORG L. 2013. RBE of low energy electrons and photons. Phys Med Biol 55(10): 65-109

Pogozelski W, ARPAiA N AND O'DONNELl R. 2006. Induction of the common deletion in mitochondrial DNA by gama radiation and absolute quantification by real-time PCR. Abstracts / Mitochondrion 6: 281.

Prithivirajsingh S, Story MD, Bergh SA, Geara FB, ANG KK, Ismail SM, Stevens CW, BuchHolz TA AND BROCK WA. 2004. Accumulation of the common mitochondrial DNA deletion induced by ionizing radiation. FEBS Lett 571(1-3): 227-232.

RIJSWIJK S, HUIJBREGTS MAJM, LUST E AND STRACK VAN SCHIJNDEL RJM. 2008. Mini-review on cardiac complications after mediastinal irradiation for Hodgkin lymphoma. Neth J Med 66(6): 234-237.

RUSSELL LK, FINCK BN AND KELLY DP. 2005. Mouse models of mitochondrial dysfunction and heart failure. J Mol Cell Cardiol 38(1): 81-91.

SCHULTZ-HECTOR S. 1992. Radiation-induced heart disease: review of experimental data on dose response and pathogenesis. Int J Radiat Biol 61(2): 149-160.
SHOKOLEnKo I, Venediktova N, BochKareva A, WiLson GL AND ALEXEYEV MF. 2009. Oxidative stress induces degradation of mitochondrial DNA. Nucleic Acids Res 37(8): 2539-2548.

WANG L, KuWAhara Y, Li L, Baba T, Shin R, OHKUbo Y, OnO K AND FuKumoto M. 2007. Analysis of Common Deletion (CD) and a novel deletion of mitochondrial DNA induced by ionizing radiation. Int J Radiat Biol 83(7): 433-442.

WARDELl TM, Ferguson E, CHINNERY PF, BORTHWICK GM, TAYLOR RW, JACKSON G, CRAFT A, LightOWLERS RN, Howell N AND TuRnBUll DM. 2003. Changes in the human mitochondrial genome after treatment of malignant disease. Mutat Res 525(1-2): 19-27.

Ye C, Shu X, Wen W, Pierce L, Courtney R, Gao Y, Zheng W AND CAI Q. 2008. Quantitative analysis of mitochondrial DNA 4977-bp deletion in sporadic breast cancer and benign breast diseases. Breast Cancer Res Treat 108(3): 427-434.

ZHONG Y, HU YJ, YANG Y, PENG W, SUN Y, CHEN B, HUANG $\mathrm{X}$ AND KONG WJ. 2011. Contribution of common deletion to total deletion burden in mitochondrial DNA from inner ear of d-galactose-induced aging rats. Mutat Res 712(1-2): 11-19. 